Hoffbrand, A. V., et al. (1971). Gut, 12, 27.

Jelliffe, O. B. (editor) (1966). Assessment of the Nutritional Status of the Community. Geneva, World Health Organization

Kamer, J. H. Van der. (1958). In Standard Methods of Clinical Chemistry, ed. D. Seligson, Vol. 2, p. 34. New York, Academic Press.

Klipstein, F. A., (1969). Blood, 34, 191.

Klipstein, F. A., and Baker, S. J. (1970). Gastroenterology, 58, 717.

Klipstein, F. A., et al. (1968). American fournal of Clinical Nutrition, 21, 1042 .

Lindenbaum, J. (1973). Gastroenterology, 64, 637

Lindenbaum, J., Kent, T. H., and Sprinz, H. (1966). Annals of Internal Medicine, 65, 1201 .

Manson-Bahr, P. H. (1965). Lancet, 2, 839.

Mathan, V. I., and Baker, S. J. (1971). Tropical Sprue and Megaloblastic Anaemia, London, Churchill.
Mayoral, L. G., et al. (1968). American fournal of Clincial Nutrition, 21, 1053. Mollin, D. L., and Booth C. C. (1971). Tropical Sprue and Megaloblastic Anaemia. London, Churchill.

Montgomery, R. D., et al. (1973). British Medical fournal, 2, 265.

O'Bien, W., and England, N. W. J. (1971). Tropical Sprue and Megaloblastic Anaemia. London Churchill.

Roe, J. H., and Rice E. W. (1948). Fournal of Biological Chemistry, 173, 507. Rowe, B., Taylor, J., and Bettleheim, K. A. (1970). Lancet, 1, 1.

Sheehy, T. W., and Anderson, P. R. (1963). Lancet, 2, 1

Sheehy, T. W., et al. (1965). Fournal of the American Medical Association 194, 1069 .

Society of Actuaries. (1966). In Assessment of the Nutritional Status of the Community, ed. D. B. Jelliffe, p. 239. Geneva, World Health Organiza-

Walters, J. H. (1947). Lancet, 1, 861.

\title{
Blood Glucose Measurement with Dextrostix and New Reflectance Meter
}

\author{
BENGT SCHERSTEN, CLAUS KUHL， ANDERS HOLLENDER， ROLF EKMAN
}

British Medical fournal, 1974, 3, 384-387

\begin{abstract}
Summary
A new instrument, Eyetone, has been produced for use with a Dextrostix reagent strip for estimating blood sugar levels. It differs from the Dextrostix Reflectance Meter in having only one meter scale, a two-point calibration, and a range of measurement limited to $10-400$ $\mathrm{mg} / \mathbf{1 0 0} \mathrm{ml}$. Results with the manufacturers' original calibration were unsatisfactory, but when recalibrated the performance of the instrument gave a regression equation line close to the ideal. The three Eyetone instruments tested were comparable in their accuracy and functional stability. Packed cell volumes in the blood samples in the range of $30-50 \%$ had a negligible effect on the results. The Dextrostix-Eyetone method represents a quick and reliable alternative to conventional laboratory methods for blood sugar estimation. It is especially useful for patients outside hospital.
\end{abstract}

\section{Introduction}

The introduction in 1970 of the Dextrostix Reflectance Meter, which recorded electronically the blood glucose concentration equivalent of a colour on a Dextrostix reagent strip, was a valuable advance in the technology of blood sugar measurement. It obviated observer variations inevitable in the evaluation of colour (Cohen et al., 1964; Rennie et al., 1964; Scherstén, 1965) and it enabled blood sugar levels to be

\footnotetext{
Community Health Research Centre, Dalby, and Department of Internal Medicine, University Hospital of Lund, Sweden

BENGT SCHERSTÉN, M.D., Associate Professor of Medicine

Department of Internal Medicine, Bispebjerg Hospital, University of Copenhagen, Denmark

CLAUS KUHL, M.D., Research Fellow

Department of Clinical Chemistry, County Central Hospital, Boras, ANDERS HOLLENDER, M.D., Physician-in-Chief Department of Clinical Chemistry, University Hospital of Lund,
Sweden

ROLF EKMAN, M.D., Senior Registrar
}

measured accurately and rapidly without resort to laboratory assistance. Nevertheless, the instrument, though reliable in the middle range of blood glucose levels most commonly seen when treating diabetics (Jarrett et al., 1970; Joffe and Seftel, 1971; Scherstén, 1971; Forman et al., 1972; Percy-Robb et al., 1972; Kühl, 1973), has been criticized for being unreliable with very low levels and those above $200 \mathrm{mg} / 100 \mathrm{ml}$ (Junker and Ditzel, 1972; Kühl, 1973). In 1973 a new instrument, Eyetone, was introduced. This has a single meter scale for whole blood glucose levels in the range of $10-400 \mathrm{mg} / 100 \mathrm{ml}$; has two calibration strips, which allows for two-point calibration; and is mainsoperated. This paper reports on a multicentre study of the Dextrostix-Eyetone method of blood sugar estimation.

\section{Materials and Methods}

The directions in the operating manual for handling the Dextrostix strip and the Eyetone instrument were followed precisely. The recommended calibration points of 50 and $400 \mathrm{mg} / 100 \mathrm{ml}$ were later changed by the manufacturer to 40 and $300 \mathrm{mg} /$ $100 \mathrm{ml}$. A special study of standardization was therefore made at one centre.

Samples of venous blood were taken from both non-diabetics and diabetics and an anticoagulant (heparin or edetic acid) was added. Hypoglycaemic and hyperglycaemic specimens were also prepared-the former by allowing spontaneous glucolysis to occur in blood standing in a stoppered container at room temperature for several hours, and the latter by adding pure dextrose or a concentrated aqueous glucose solution.

The findings with the Dextrostix-Eyetone method were compared with those with the following three reference methods. Centre 1 (Community Health Centre, Dalby, and University Hospital of Lund) used the glucose oxidase method of Marks (1959) as modified by Brandt et al. (1964) together with a Vitatron UC 200. The mean day-to-day coefficient of variation for this method during two years was $3 \cdot 2 \pm$ S.D. $0.8 \%$ with a $95 \%$ confidence limit of $1 \cdot 5-5 \cdot 0 \%$. Centre 2 (University Hospital of Copenhagen) used the hexokinase method of Widdowson and Penton (1972) together with an AutoAnalyzer II. The day-to-day coefficient of variation during one month was $3 \cdot 4 \%$. Centre 3 (County Central Hospital, Borås) used the o-toluidine method of Hultman $(1957,1959)$ together with an AutoAnalyzer I. The day-to-day coefficient of variation during seven months was $3.6 \%$.

Comparison of these three reference methods showed a high 
degree of correlation, the coefficient of correlation being 0.99 in each comparison.

The accuracy of the Dextrostix-Eyetone method was assessed by recovery experiments as well as by parallel measurements with the reference methods. The recovery experiments were made at centre 1 by adding 10-60 $\mu$ l of a highly concentrated glucose solution. Also used throughout as a control was a standard solution, provided by the manufacturer, equivalent to a whole blood glucose concentration of $105 \mathrm{mg} / 100 \mathrm{ml}$. It consisted of an aqueous solution of glucose with povidone stabilized with benzoic acid and sodium chloride and coloured to resemble fresh venous blood. The viscosity was the same as that of venous blood.

The range of accuracy of the Dextrostix-Eyetone method was assessed by carrying out 25 consecutive measurements of blood glucose concentrations in each of four samples containing various amounts of glucose. Variations among test strips was investigated by doing 75 estimations on one blood sample with strips from three different batches. Differences in performance by three Eyetone instruments were evaluated in a series of different blood samples by reading each strip in each instrument within 15 seconds in random order.

The performance of the Dextrostix-Eyetone method in clinical use was assessed by comparing the results obtained with it by six laboratory workers with the results obtained with the hospital's routine method of estimation. Capillary blood for use in both methods was collected simultaneously. Significant loss of glucose was prevented by keeping the samples at $4^{\circ} \mathrm{C}$ (Scherstén, 1965). In all 200 parallel measurements were made.

\section{PACKED CELL VOLUME}

Because of reports (Zalme and Knowles, 1965; Haworth et al., 1972; Kutter, 1973) that the results of blood sugar estimations were affected by the packed cell volume this volume was measured for each sample and its effect on the DextrostrixEyetone and reference methods compared. To eliminate the differences between the two methods at various levels of blood glucose the samples were separated into the following eight groups, according to the glucose level found by the reference method-0-50, 51-100, 101-150, 151-200, 201-250, 251-300, $301-350$, and $351-400 \mathrm{mg} / 100 \mathrm{ml}$. For each observation within each group the quotient Eyetone/reference method was calcu-

lated and summarized as $\sum \frac{\text { Eyetone }}{\text { Reference method }} i$,

where i represents the relevant group. The number of observations within the group $\left(\mathrm{N}_{\mathbf{i}}\right)$ was then divided by

$$
\sum \frac{\text { Eyetone }}{\text { Reference method }} \text {. }
$$

this way a factor was obtained by which each Eyetone/reference method quotient had to be multiplied to eliminate the effect of the blood glucose level. The value that was compared with the packed cell volume value was therefore

$$
\frac{\text { Eyetone }}{\text { Reference method }}\left[\sum \frac{\frac{\mathrm{N}_{\mathrm{i}}}{\text { Eyetone }}}{\text { Reference method }} \mathrm{i}\right]
$$

The mean of the values thus obtained within each group was equal to one.

\section{Results}

The original calibration points $(50$ and $400 \mathrm{mg} / 100 \mathrm{ml}$ ) and also those recommended later $(40$ and $300 \mathrm{mg} / 100 \mathrm{ml}$ ) clearly gave regression equations significantly different from the ideal line (table I). Therefore, various calibration points were studied. Those that gave a regression line as close as possible to the ideal, 40 and $280 \mathrm{mg} / 100 \mathrm{ml}$, were chosen for further studies at centre 1 .

\begin{tabular}{|c|c|c|c|c|}
\hline \multirow{2}{*}{$\begin{array}{c}\text { Calibration } \\
\text { Set-points } \\
(\mathrm{mg} / 100 \mathrm{ml})\end{array}$} & \multirow{2}{*}{$\begin{array}{c}\text { Regression } \\
\text { Equation } \\
\mathrm{y}(\text { Eyetone })=\mathrm{a}+\mathrm{b} \times *\end{array}$} & \multicolumn{2}{|c|}{$\mathbf{P}$} & \multirow{2}{*}{$\begin{array}{c}\text { Coefficient } \\
\text { of } \\
\text { Correlation }\end{array}$} \\
\hline & & $a \pm 0$ & $b \pm 1$ & \\
\hline $\begin{array}{l}50-400 \\
50-320 \\
40-300 \\
40-260 \\
40-280\end{array}$ & $\begin{array}{l}y=14.9+1.15 \times \\
y=2.4+1.21 \times \\
y=9.5+1.12 \times \\
y=16.4+0.89 \times \\
y=7.5+1.001 \times\end{array}$ & $\begin{array}{l}<0.05 \\
>0.05 \\
>0.05 \\
<0.05 \\
>0.05\end{array}$ & $\begin{array}{l}<0.001 \\
<0.001 \\
<0.01 \\
<0.05 \\
>0.05\end{array}$ & $\begin{array}{l}0.98 \\
0.97 \\
0.96 \\
0.96 \\
0.97\end{array}$ \\
\hline
\end{tabular}

TABLE I-Recalibration Study

$\mathrm{y}=\mathrm{a}+\mathrm{b} \times$, where $\mathrm{a}$ is the intercept of the regression line and $\mathrm{b}$ is the slope or coefficient of the regression line.

The correlation between the reference method and the Eyetone instrument calibrated at 40 and $280 \mathrm{mg} / 100 \mathrm{ml}$ found at centre 1 is shown in fig. 1 . The regression lines obtained at centres 2 and 3, where the calibration points 40 and $300 \mathrm{mg} /$ $100 \mathrm{ml}$ were used, are shown in figs. 2 and 3.

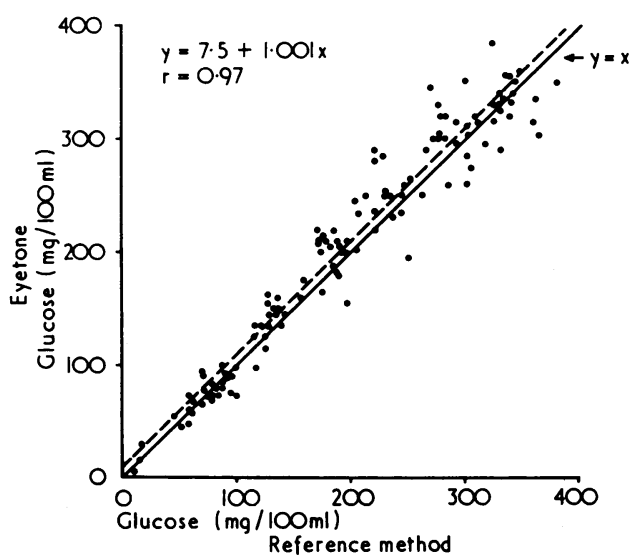

FIG. 1-Correlation between results by Eyetone and glucose oxidase reference method (Marks, 1959) at centre 1 using calibration points 40 and $280 \mathrm{mg}$ / $100 \mathrm{ml}$

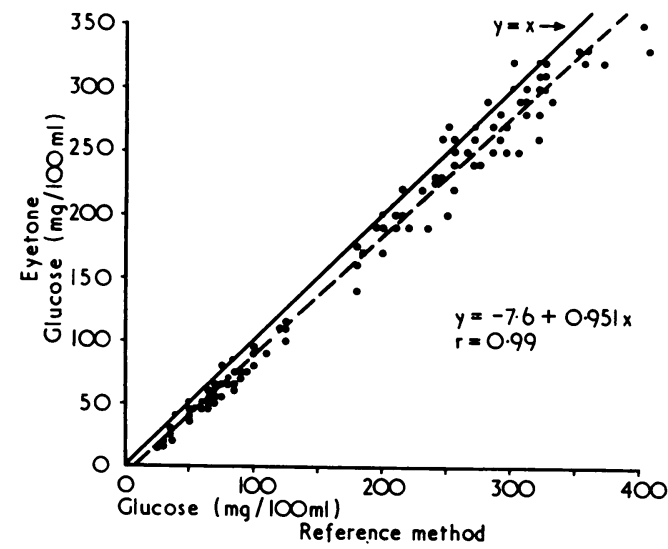

FIG. 2-Correlation between results by Eeytone and hexokinase reference method (Widdowson and Penton, 1972) at centre 2 using calibration points 40 and $300 \mathrm{mg} / 100 \mathrm{ml}$.

In the recovery trial the mean recovery percentage for the Eyetone instrument ranged between 100.7 and $115.2 \%$ and that for the reference method between 89.6 and $100.9 \%$ (table II). The results at the other centres were similar.

The day-to-day coefficients of variation for the three Eyetone instruments were close to $5 \%$ (table III) and were of the same magnitude as those of the reference methods. The range of accuracy of the instrument was shown (table IV) by the coefficient of variation found in 25 replicate analyses of four blood samples containing various concentrations of glucose. When studying the variability of the Dextrostix strips by measuring 


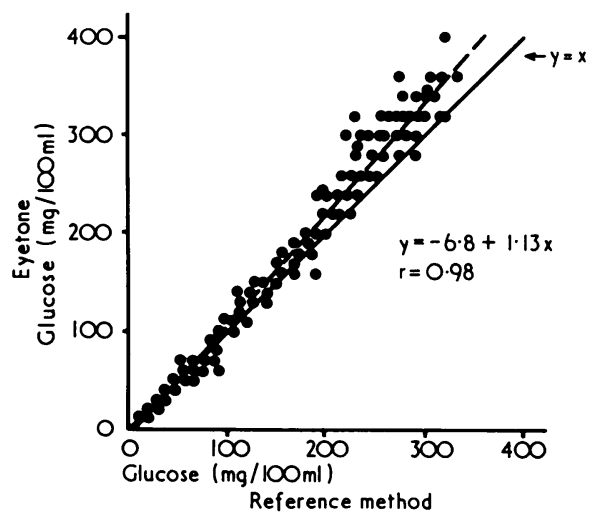

FIG. 3-Correlation between results by Eyetone and o-toluidine method (Hultman, 1957, 1959) at centre 3 using calibration points 40 and $300 \mathrm{mg} /$ $100 \mathrm{ml}$.

TABLE II-Results of Recovery of Added Glucose by Eyetone and Reference Methods

\begin{tabular}{|c|c|c|c|c|c|}
\hline \multirow{3}{*}{$\begin{array}{c}\text { No. of } \\
\text { Experi- } \\
\text { ments }\end{array}$} & \multirow{3}{*}{$\begin{array}{c}\text { Added } \\
\text { Glucose } \\
(\mathrm{mg} / 100 \mathrm{ml})\end{array}$} & \multicolumn{4}{|c|}{ Recovery } \\
\hline & & \multicolumn{2}{|c|}{ Eyetone } & \multicolumn{2}{|c|}{ Reference Method } \\
\hline & & $\underset{(\mathrm{mg} / 100 \mathrm{ml})}{\text { Mean }}$ & $\%$ & $\underset{(\mathrm{mg} / 100 \mathrm{ml})}{\operatorname{Mean} \pm \text { S.D. }}$ & $\%$ \\
\hline $\begin{array}{l}21 \\
21 \\
21 \\
21 \\
21\end{array}$ & $\begin{array}{r}50 \\
100 \\
150 \\
200 \\
250\end{array}$ & $\begin{array}{r}57.6 \pm 9.1 \\
114.4 \pm 19.2 \\
163.7 \pm 22.9 \\
217.6 \pm 18.0 \\
251.8 \pm 19.3\end{array}$ & $\begin{array}{l}115 \cdot 2 \\
114 \cdot 4 \\
109 \cdot 1 \\
108 \cdot 8 \\
100 \cdot 7\end{array}$ & $\begin{array}{r}44.8 \pm \quad 4.9 \\
97.2 \pm \pm 5.8 \\
144.8 \pm 14.5 \\
201.8 \pm 13.6 \\
246.2 \pm 17.7\end{array}$ & $\begin{array}{r}89.6 \\
97.2 \\
96.5 \\
100.9 \\
98.5\end{array}$ \\
\hline
\end{tabular}

TABLE III-Day-to-day Coefficients of Variation of Evetone Instruments at Three Reference Centres in estimating Standard Glucose Solution of $105 \mathrm{mg}$ $100 \mathrm{ml}$

\begin{tabular}{lll|r|c}
\hline & & & $\begin{array}{c}\text { Mean } \pm \text { S.D. } \\
(\mathrm{mg} / 100 \mathrm{ml})\end{array}$ & $\begin{array}{c}\text { Coefficient of Variation } \\
(\%)\end{array}$ \\
\hline Centre 1 & $\cdots$ & $\cdots$ & $108 \cdot 0 \pm 5 \cdot 7$ & $5 \cdot 3$ \\
Centre 2 & $\cdots$ & $\cdots$ & $104 \cdot 0 \pm 5 \cdot 0$ & $4 \cdot 8$ \\
Centre 3 & $\cdots$ & $\cdots$ & $106 \cdot 4 \pm 6 \cdot 1$ & $5 \cdot 7$ \\
\hline
\end{tabular}

TABLE IV-Range of Accuracy of Eyetone Instrument as shown by Percentage Coefficient of Variation in Results of Replicate Analyses of Four Blood samples containing Various Amounts of Glucose

\begin{tabular}{c|c|c}
\hline $\begin{array}{c}\text { No. of } \\
\text { Replicate Analyses }\end{array}$ & $\begin{array}{c}\text { Mean Eyetone } \\
\text { Blood Glucose } \\
(\mathbf{m g} / 100 \mathrm{ml})\end{array}$ & $\begin{array}{c}\text { Coefficient of Variation } \\
(\%)\end{array}$ \\
\hline 25 & 30 & 0 \\
25 & 51 & $5 \cdot 5$ \\
25 & 167 & $5 \cdot 0$ \\
25 & 245 & $4 \cdot 9$ \\
\hline
\end{tabular}

the same blood samples 75 times (mean glucose concentration $97 \mathrm{mg} / 100 \mathrm{ml}$ ) a somewhat higher coefficient of variation of $8.7 \%$ was found, which indicated some degree of heterogeneity among the strips.

The effect of the packed cell volume on the findings by the Dextrostix-Eyetone method was negligible within the range (30-50\%) studied (fig. 4).

Comparison of the performance of the Eyetone instruments, using the calibration points 40 and $280 \mathrm{mg} / 100 \mathrm{ml}$ in all three, showed them to be almost equal (figs. 5 and 6).

When, as a result of our findings, the manufacturuer recalibrated the strips at set points of 40 and $290 \mathrm{mg} / 100 \mathrm{ml}$ all three instruments measured the $105 \mathrm{mg} / 100 \mathrm{ml}$ standard control glucose solution as $104.5 \pm 5.6 \mathrm{mg}$ (mean \pm S.D.) with a coefficient of variation of $5.4 \%$. The recalibrated strips were used in assessing the accuracy of the Dextrostix-Eyetone method in routine clinical use. The results of 200 measurements made in parallel with the hospital's usual method of estimation showed a

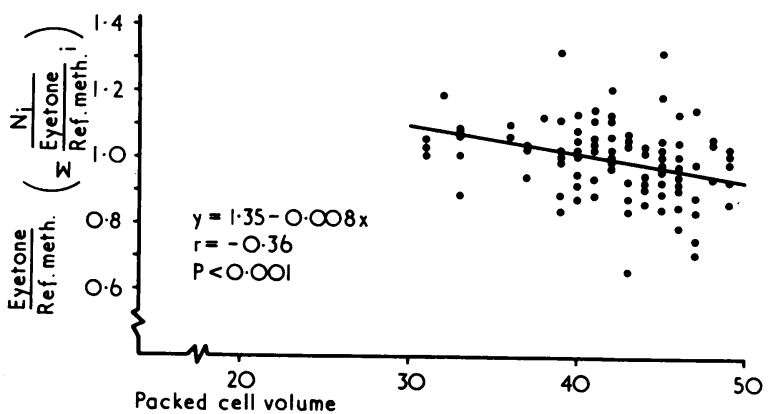

FIG. 4-Relation betwen packed cell volume and blood glucose as determined by Eyetone method. For explanation of symbols see text.

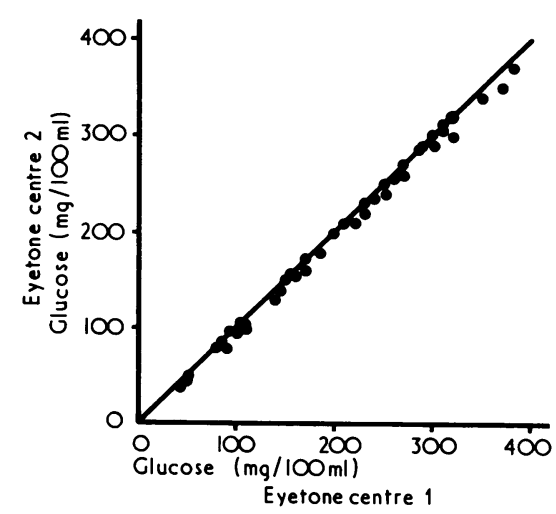

FIG. 5-Comparison of blood glucose measurements by Eyetone instruments at centres 1 and 2 .

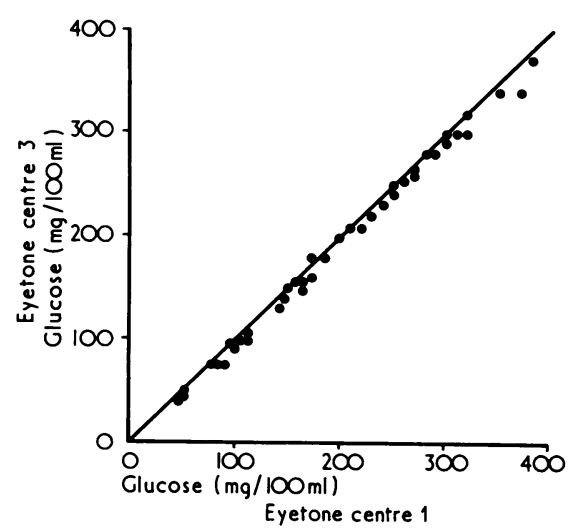

FIG. 6-Comparison of blood glucose measurements by Eyetone instruments at centres 1 and 3 .

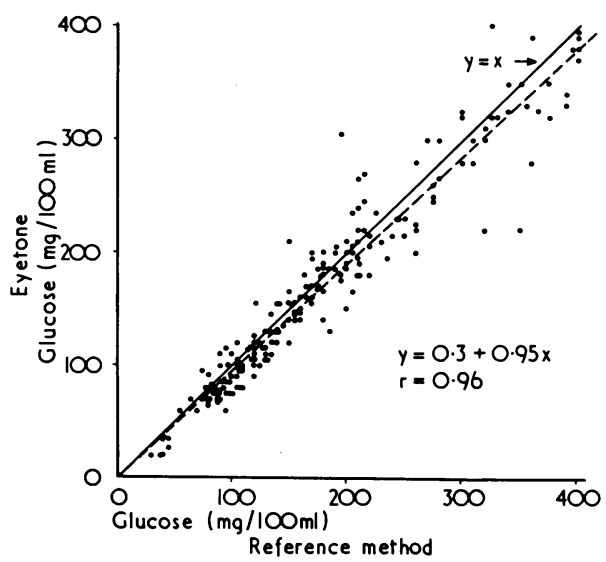

FIG. 7-Comparison of routine clinical blood glucose measurements by Eyetone and glucose oxidase method (Marks, 1959) in 200 parallel determinations. 
somewhat higher degree of deviation (fig. 7), indicating that those who use the method must be properly trained. None of the five most divergent results led to a wrong insulin dosage. The clinicians found that results could be obtained two to three hours quicker by the Dextrostix-Eyetone method than by the method to which they were accustomed.

\section{Discussion}

Blood glucose levels above $400 \mathrm{mg} / 100 \mathrm{ml}$ are outside the range measured by the Dextrostix-Eyetone method. This limits its clinical use, especially in the treatment of diabetic coma. On the other hand, the accuracy of the Eyetone instrument in measuring the levels of blood sugar commonly found in diabetics is highly satisfactory. Furthermore, packed cell volumes in the range of $30-50 \%$ had little effect on the accuracy of the method, a finding which is contrary to that of Kutter (1973). Nor did we find the differences in performance of the Eyetone instruments that Junker and Ditzel (1972) found in the Dextrostix Reflectance Meter instruments.

Compared with the Dextrostix Reflectance Meter instrument the Eyetone calibrates at two different blood glucose levels instead of one, an improvement which had often been suggested by those using the Dextrostix Reflectance Meter (Scherstén, 1971; Kühl, 1973). After we had found that the best results were obtained when the calibration points were set at 40 and $280 \mathrm{mg} / 100 \mathrm{ml}$, and the three instruments were adjusted to that setting, each one measured blood glucose concentrations in the range $10-400 \mathrm{mg} / 100 \mathrm{ml}$ with equal accuracy. The differences observed between the regression equations at centres 1 and 3 when using the same calibration points of 40 and $300 \mathrm{mg} / 100 \mathrm{ml}$ can therefore be explained by the difference in the reference methods used and not by variance in the Eyetone instruments. The original calibration strips set at 50 and $400 \mathrm{mg} / 100 \mathrm{ml}$ have now been altered by the manufacturer to equate with our findings. When the new strips were matched against the strips we had used all three instruments gave readings of 40 and $290 \mathrm{mg} / 100 \mathrm{ml}$, which were thus in near agreement with our results. Furthermore, when the instrument was checked against a standard control glucose solution of $105 \mathrm{mg} / 100 \mathrm{ml}$ the results were fully acceptable. Using this standard control solution of glucose we also studied the day-to-day variance of the method over a period of three months and found a coefficient of variation around $5 \%$. This indicates a high degree of functional stability of the instrument. Nevertheless, a similar study using a stronger glucose solution of, say, $350 \mathrm{mg} / 100 \mathrm{ml}$ is desirable.

Our results with the Dextrostix-Eyetone method of blood sugar measurement show that it represents a quick and reliable alternative to a conventional laboratory method, especially for use outside hospital. Adequate training in the technique is essential, and the performance of each instrument should be checked at regular intervals.

We are grateful to Ames Company, Scandinavia, and in particular to Dr. A. Wagner, for supplying us with the instruments tested. We also thank Miss Monica Johansson, Miss Ingbritt Åstrand, Mrs. Siv Olsson, Mrs. Helene Arndal, and Mrs. Ulla Birger Jensen for their skilled laboratory help. The statistical work was performed with the help of Mr. G. Ejlertsson, whom we also thank.

Requests for reprints should be addressed to: Dr. Bengt Schersten, Dalby Community Health Research Centre, Dalby, Sweden.

\author{
References \\ Brandt, L., Nordén, A., Scherstén, B., and Tryding, N. (1964). Acta \\ Medica Scandinavica, 176, 555. \\ Cohen, S. L., Legg, S., and Bird, R. (1964). Lancet, 2, 883. \\ Forman, D. T., Grayson, S. H., and Slonicki, A. (1972). Laboratory \\ Medicine, 3, 26. \\ Haworth, J. C., Dilling, L. A., and Van Woert, M. (1972). American fournal \\ of Diseases of Children, 123, 469. \\ Hultman, E. (1957). Scandinavian Fournal of Clinical and Laboratory \\ Investigation, 10, Suppl. No. 31, p. 278 \\ Hultman, E. (1959). Nature, 180, 108. \\ Jarrett, R. J., Keen, H., and Hardwick, C. (1970). Diabetes, 19, 724 \\ Joffe, B. J., and Seftel, H. C. (1971). South African Medical Fournal, 45, 1200. \\ Junker, K., and Ditzel, J. (1972). Lancet, 1, 815 . \\ Kühl, C. (1973). Ugeskrift for Lager, 135, 66. \\ Kutter, D. (1973). Diagnostik, 6, 671. \\ Marks, V. (1959). Clinica Chimica Acta, 4, 395. \\ Percy-Robb, J. W., McMaster, R. S., and Duncan, L. J. P. (1972). Annals \\ of Clinical Biochemistry, 9,91 . \\ Rennie, J. D. B., Keen, H., and Southon, A. (1964). Lancet, 2, 884. \\ Scherstén, B. (1965). Acta Medica Scandinavica, 178, 583. \\ Scherstén, B. (1971). Läkartidningen, 68, 4001. \\ Widdowson, G. M. and Penton, J. R (1972). Clinical Chemistry, 18, 299. \\ Zalme, E., and Knowles, H. C. (1965). Diabetes, 14, 165.
}

\section{Summary}

A patient is described who developed renal failure due to a severe proliferative glomerulonephritis with hypocomplementaemia and cryoglobulinaemia while repeatedly injecting herself with diphtheria, pertussis, and tetanus vaccine (D.P.T. vaccine). After stopping the antigen administration there was recovery of renal function,

\footnotetext{
Departments of Medicine and Pathology, Royal Postgraduate Medical School, Ducane Road, London W12 OHS

J. M. BOULTON-JONES, M.B., M.R.C.P., Senior Registrar

J. G. P. SISSONS, M.B., M.R.C.P., Registrar

P. F. NAISH, M.B., M.R.C.P. (Present appointment: Consultant Physician, North Staffordshire Royal Infirmary, Stoke-on-Trent)

D. J. EVANS, M.B., Senior Lecturer in Histopathology

D. K. PETERS, M.B., M.R.C.P., Lecturer in Medicine and Immunology
}

complement values returned to normal, and cryoglobulin could no longer be recovered from the sera. The pathogenesis of the glomerulonephritis is discussed.

\section{Introduction}

In experimental animals the generation of circulating antigenantibody complexes by the repeated administration of serum protein antigens, such as bovine albumin, has been shown to produce glomerular disease lesions closely resembling human chronic glomerular disease (Dixon et al., 1961; Germuth et al., 1957). Immunofluorescent studies of renal biopsy material have shown that the glomerular deposits of immunoglobulin and complement are found in most human nephritides, suggesting that these are mediated by immune complexes (Berger et al., 1971 ; McCluskey, 1971). It is only rarely possible, however, to show circulating antigen-antibody complexes or to identify the antigenic component of the complex in the glomerular deposits. We therefore thought it would be of interest to report a patient 